\title{
Digital Marketing as a Marketing Communication Strategy
}

\author{
A Rizaldi ${ }^{1}$, F Margareta ${ }^{2 *}$, K Simehate ${ }^{3}$, S N Hikmah ${ }^{4}$, C N Albar ${ }^{5}$, \\ A A Rafdhi6 \\ ${ }^{1}$ Departemen Manajemen, Universitas Komputer Indonesia, Indonesia \\ 2,3Departemen Akuntansi, Universitas Komputer Indonesia, Indonesia \\ ${ }^{4}$ Departemen Ilmu Komunikasi, Universitas Komputer Indonesia, Indonesia \\ ${ }^{5}$ Departemen Sastra Inggris, Universitas Komputer Indonesia, Indonesia \\ ${ }^{6}$ Departemen Sistem Informasi, Universitas Komputer Indonesia, Indonesia \\ Email: *farida.21118020@mahasiswa.unikom.ac.id
}

\begin{abstract}
Digital marketing is a strategy that is quite impactful to increase the number of consumers in the organic fertilizer business sector in an era like today. The purpose of this research is to analyze the marketing strategy of organic fertilizers and the increase in the number of consumers. The research method used was escriptive methods, namely data collection and questionnaires. Methods of data collection carried out by observation, interviews and literature study. The questionnaire was used in analyzing consumers who use organic fertilizers on chilies. The results of this research show that digital marketing as marketing communication is useful in increasing selling power and promotion. This study discusses the use of digital marketing in marketing communications and whether consumers prefer organic fertilizers or not.
\end{abstract}

\section{Introduction}

The advancement of information technology nowadays provides a very rapid change in the world of marketing in the last few years. The method of marketing communication that was previously offline which received information from people has now changed to an integrated online or digital world [1]. Using technology in product marketing activities that take advantage of the sophistication of digital technology is called digital marketing. Online business systems are easier to implement and do not require a large investment both at the start and when operating. It only requires a good internet connection as initial capital to build this online business. Digital marketing consists of interactive and integrated marketing that facilitates interaction between producers, market intermediaries and potential consumers [2]. Digital marketing has a strategic role to market its business products, namely using social media as marketing communications. Social media is used to advertise or promote a product so that consumers are attracted to try and buy products through information obtained on social 


\section{International Journal of Research and Applied Technology}

1(1)(2021) 61-69

Journal homepage: https://ojs.unikom.ac.id/index.php/injuratechInternational

media. Social media is an online media that is used to obtain information in the form of text, images, video and audio which allows users to take advantage of doing business [3]. Marketing strategy is a marketing communication that aims to provide information to the community, especially consumers who are the target of a product. The concept is generally used to provide information or so-called advertising promotion mix, sales promotion, personal selling, direct selling, public relations and publicity [4]. The marketing management process consists of analyzing market opportunities, researching and selecting target markets by planning marketing strategies, managing marketing programs, implementing and supervising marketing efforts. This can be implemented by analyzing marketing opportunities, researching and selecting targeted communities, designing marketing strategies by making marketing costs, determining the marketing mix consisting of product, price, promotion, and place. Product allocation and organizing, implement and supervise marketing performance in a company [5]. Marketing communication can also be stated as a communication activity that aims to convey messages to consumers by using various media, with the hope that communication can produce three stages of change, namely changes in knowledge, changes in attitudes and changes in desired actions. Marketing communication is also a form of communication that aims to strengthen marketing strategies, in order to achieve a wider segmentation. This study can also be said to be an effort to strengthen customer loyalty to products, namely goods and services owned by the company. What a marketer needs to understand is that the success of a marketing communication strategy can be measured by how much the sale of a product or income from the use of services by consumers [6]. The basic function of marketing communication itself is how through a communication can influence targets to make purchases of goods and services. Online marketing or e-marketing is one component of e-commerce that focuses on market players. Online marketing is a strategic process in creating, transforming, providing, and providing good prices and services to target markets via the internet or digital media. [7].

Research related to digital marketing has been done before. This increasingly makes researchers interested in continuing research related to the application of digital marketing as a marketing communication strategy. Previously, there was a previous research by Fitri Rachmawati (2018), her research entitled "Application of Digital Marketing as an integrated marketing communication strategy for small and medium business (SMEs) products of the Surabaya economy heroes. From the results of the study, it was found that the communication strategy through digital marketing of the two business actors was the delivery of positioning statements in every Facebook and Instagram post as well as establishing relationships with customers by fast responding on social media [10]. As for researchers who are still related, namely digital marketing as a marketing communication strategy "Waroenk or general" in increasing the number of consumers, one of the studies conducted by Ascharisa Mettsatya Afrilia (2018). The results of this study indicate that Woreonk Ora Umum Purwokerto has utilized a digital marketing strategy which is also balanced with other marketing strategies. [1]. Then there is research conducted by Dedi Purwana, R Rahmi, Shandy Aditya (2017), which discusses the Use of Digital Marketing for Micro, Small and Medium Enterprises (MSMEs) in Malaka Sari Village, Duren Sawit. The results showed that only a few actively use social media as a means of promotion and have not separated online store accounts from their personal accounts, some others use them occasionally, and the rest never use social media marketing due to a lack of technology [2]. In addition, other research conducted by Dimas Hendika Wibowo, Zainul Arifin, Sunarti Sunarti (2015), discusses the Analysis of Marketing Strategies to Increase the Competitiveness of MSMEs (Studies on Batik Diajeng Solo). The results of the 


\section{International Journal of Research and Applied Technology}

$1(1)(2021) 61-69$

Journal homepage: https://ojs.unikom.ac.id/index.php/injuratechInternational

marketing research analysis show an increase in total sales from year to year and become a reference for marketing strategies in competition between batik companies.[5]. Kusuma, Sanya (2020). The results of the strategy implementation show that the program results in increased sales loyalty for the company. Previous studies will be compared with this study. In this study, the topic raised was Digital Marketing as a Marketing Communication Strategy. The reference used is research that is still related to the topic. Research on digital marketing as a marketing communication strategy is not new, but nothing is really similar to this research. From the results of previous research, there are similarities such as the theme raised and the method used, but it has different purposes of use with this study. The results of this study show digital marketing as a marketing communication strategy is useful in increasing selling power and promotion.

The purpose of this study is to analyze marketing strategies and introduce organic fertilizer from coffee husk waste which is rarely used by farmers specifically for chili plants and to increase the buying and selling power of various cities in Indonesia. This study used two methods, namely the descriptive method and the questionnaire method, namely the data collected comes from data analysis accompanied by asking questions through questionnaires which can help researchers more optimally in collecting data from various responses to written questions.

\section{Method}

This research is a descriptive study with a survey method. Used to describe and analyze research results, but not used to create broad messages. Meanwhile, a survey is a study that takes a sample from a population using a questionnaire as a way of collecting the required data. Then the respondents are millennials who actively use social media to get information. The research methodology in this research is: (1)Determination of attributes or dimensions that are more attractive to consumers. (2)Estimation of the model input by consumers. (3)Analysis of competitors with the same product or products that appear as substitutes. (4)Creation of incoming models from various combinations that may be entered by consumers. (5)Determine the performance of various new products developed so that greater market opportunities.

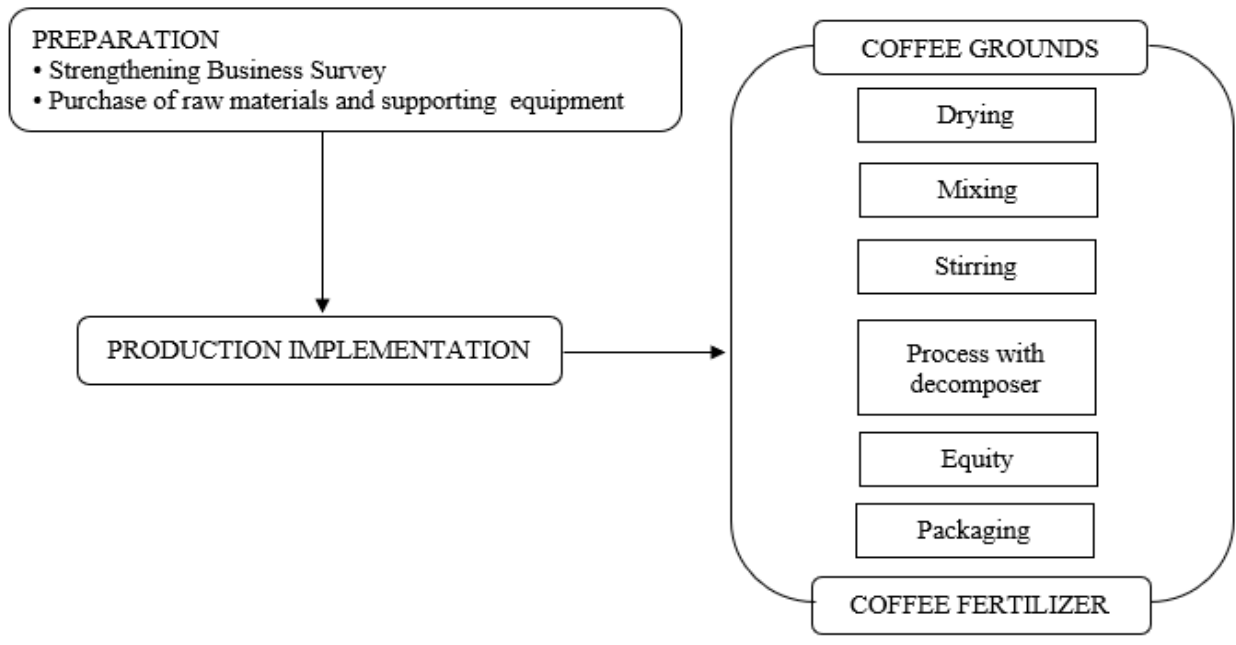

Figure 1. Initial Production Stages 


\section{International Journal of Research and Applied Technology}

$1(1)(2021) 61-69$

Journal homepage: https://ojs.unikom.ac.id/index.php/injuratechInternational

From the picture above, it is the initial stage of production to make coffee fertilizer. From the beginning of preparation, the implementation of production to become coffee fertilizer. initially from coffee grounds, then to drying, mixing, stirring, decomposer processing, equalization, to packaging. Be coffee fertilizer and coffee fertilizer are rarely used by farmers specifically for chili plants.

Descriptions of the characteristics of the respondents from this study include e-mail address, name, age and occupation. The sample used by researchers was 20 respondents or people. Are over 19 years old and most of the respondents are 21 years old. In the table below, respondents are asked the question "Do you know organic fertilizers?" and they answered yes. Meanwhile, the question "Have you ever used organic fertilizers for plants?" the response itself answers yes and no. And the question "How do you think the effect of organic fertilizers on plants?", "Do you prefer organic fertilizers or chemical fertilizers? The reason? ", "What is the reason you prefer organic fertilizers?". The respondents answered with various answers. The following table is the questions on the questionnaire (see table 1).

Tabel 1. Questions reviewed

\begin{tabular}{ll}
\hline No & \multicolumn{1}{c}{ Questions reviewed } \\
\hline 1. & Email address \\
2. & Name \\
3. & Age \\
4. & Profession \\
5. & Do you know organic fertilizers? \\
6. & Have you ever used organic fertilizers for plants? \\
7. & How do you think the effect of organic fertilizers on plants? \\
8. & Do you prefer organic fertilizers or chemical fertilizers? The reason? \\
9. & What is the reason you prefer organic fertilizers? \\
\hline
\end{tabular}

\section{Results and Discussion}

Marketing management is the science of selecting target markets that consumers acquire, maintain, and grow through the creation, delivery and value of superior customer communication. Marketing management also has a marketing strategy, namely a detailed company plan that will have an impact on various marketing programs on the demand for a product in a market that has a specific target. the marketing management process can also be carried out by analyzing marketing opportunities, researching and selecting target markets, designing marketing strategies, planning marketing programs by forming marketing costs, determining the marketing mix consisting of price, product, place, and promotion. Products, and manage the allocation, implement, and oversee the marketing performance of a company. Social media also plays an important role in the marketing process to become an effective communication tool because it has a very important role in marketing which aims to do all marketing or company activities to produce a consistent image for the company. In designing a marketing strategy with the following concepts (see Figure 2). 


\section{International Journal of Research and Applied Technology}

1(1)(2021) 61-69

Journal homepage: https://ojs.unikom.ac.id/index.php/injuratechInternational

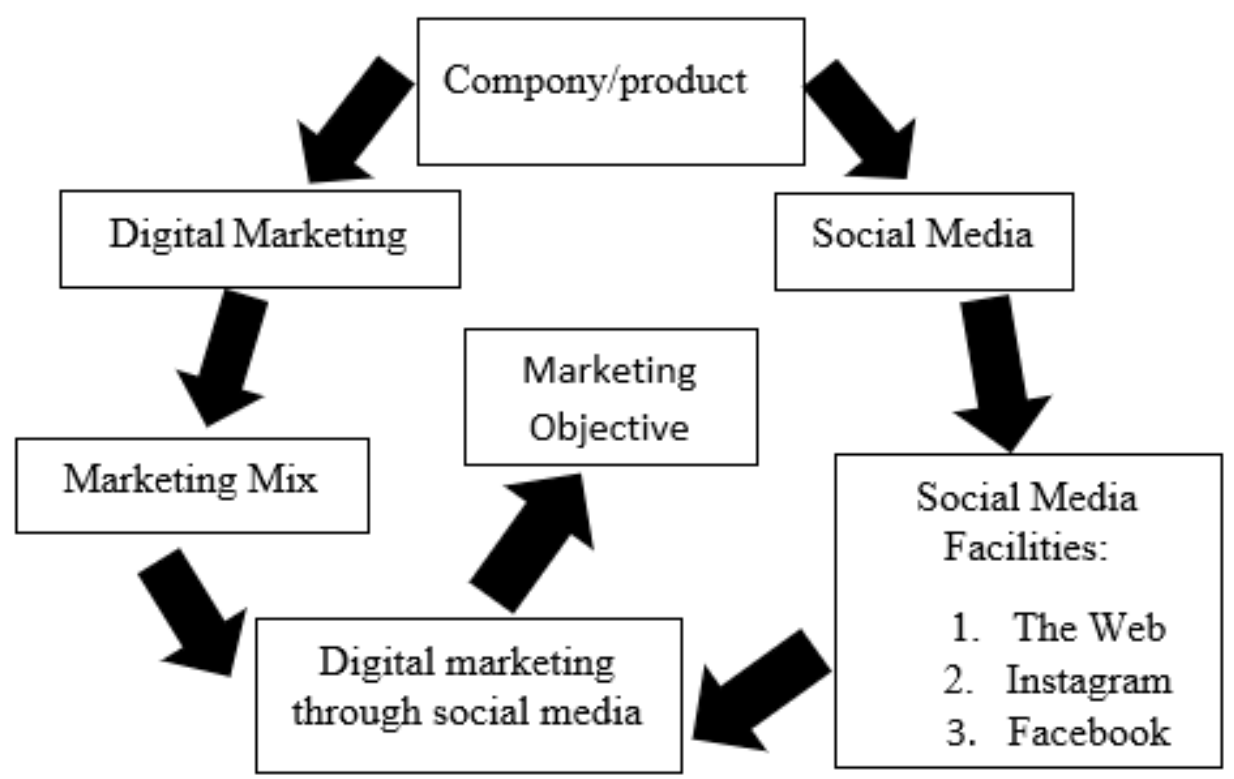

Figure 2. The concept of marketing through social

The picture above explains that marketing strategy and social media are interconnected. Companies produce products that will be promoted to consumers through social media, marketing the products must determine the marketing mix which is a sales strategy and set a unique price designed to produce mutually beneficial exchanges for the target market. In the marketing mix that must be determined, namely: the products offered according to the target market for consumer needs and can meet the needs of two parts, namely goods and services. Coffee waste fertilizer products include product line decisions, trademark decisions, packaging and label decisions, service decisions. Price is the only element of the marketing mix that generates revenue or other related elements for costs whose value is flexible / incorrect, which includes price issues, namely market prices, discounts, payment terms, and discount requirements. Place as a marketing channel, namely a group of independent organizations involved in the process of making products or services for use by consumers, products include locations (production sites, end consumers), marketing intermediaries and physical distribution. Promotion as a network / information communication media between sellers or buyers, promotion includes sales promotion, advertising, public relations and direct marketing publications or personal selling, these four things must be owned by companies in marketing a product strategy, social media facilities are used to develop or introduce products to consumers such as Instagram, online web, or other social media that support product introduction and marketing optimization of product goals. From the research results, the average person uses social media as a medium of communication, seeking information. However, coffee waste fertilizer has not been widely recognized by the public, due to the lack of product promotion and the marketing strategy has not been implemented thoroughly. The following is the percentage of using social media as a medium to buy coffee waste organic fertilizer products and the percentage of those who have tried organic fertilizer as follows (See Figure 3). 


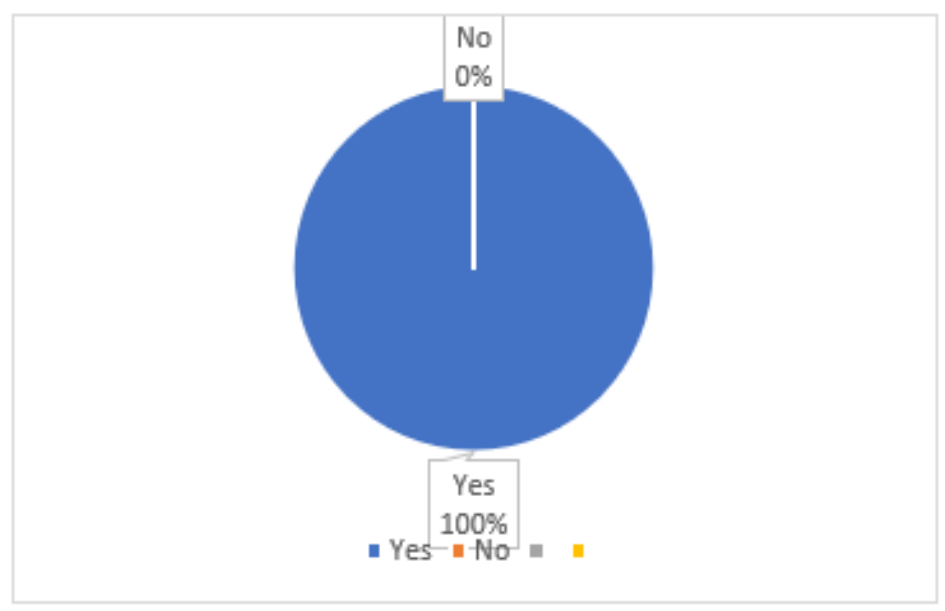

Figure 3. Qeustions about knowing organic fertilizers

The diagram shows that everyone who filled out the questionnaire knew about organic fertilizers. The respondent answered yes and the result was $100 \%$ knew about organic fertilizer. The percentage diagram shows that $89 \%$ have used organic fertilizer and $11 \%$ have never used organic fertilizer for plants (see Figure 4).

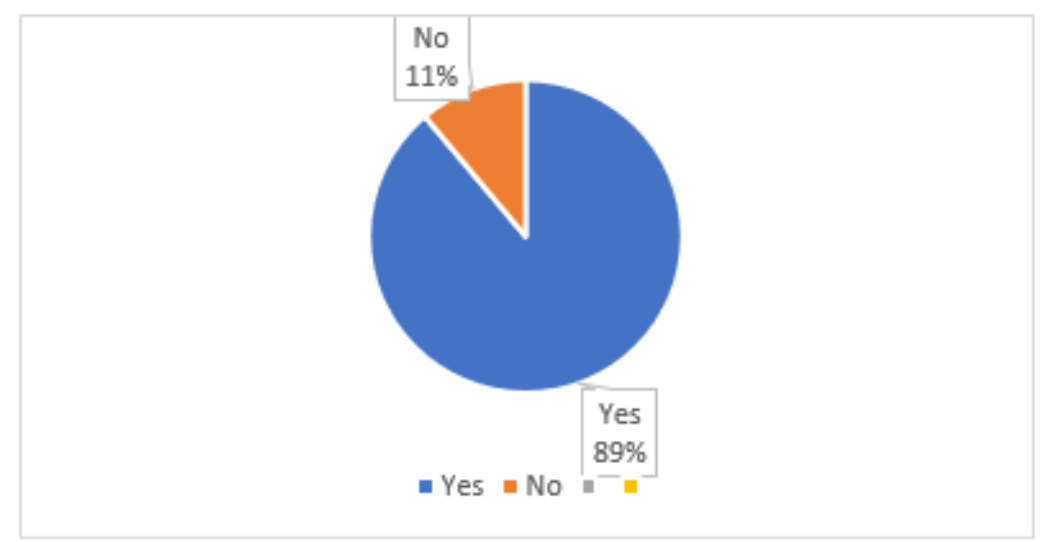

Figure 4. About ever user organic fertilizers for plants.

Based on the diagram data it can be seen that respondents who are 21 years old, namely 8 people $=40 \%$, 20 years old, 5 people $=25 \%$, while others are 19 years old, namely 1 person $=$ $5 \%$, 22 years there are 2 people $=10 \%, 23$ years there are 2 people $=10 \%$, and 28 years there are 1 people $=6 \%$ (See Figure 5). 


\section{International Journal of Research and Applied Technology}

1(1)(2021) 61-69

Journal homepage: https://ojs.unikom.ac.id/index.php/injuratechInternational

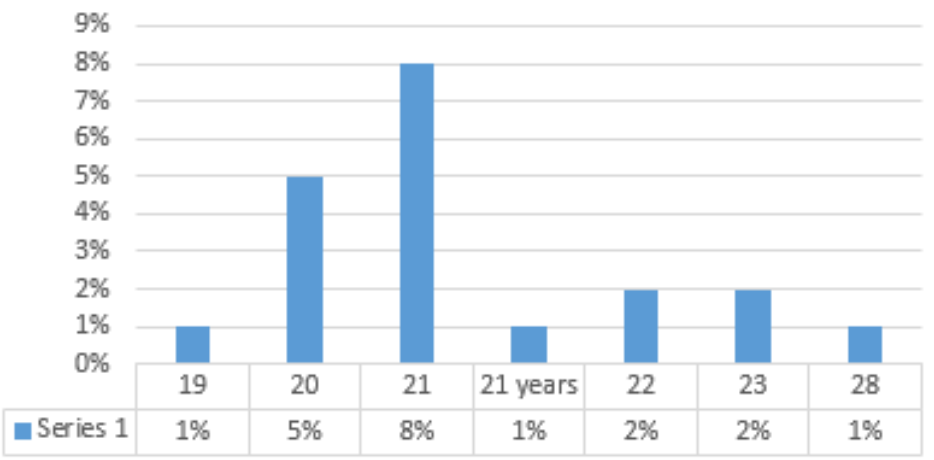

Figure 5. Respondent Age

The sample of this study used google form media to obtain information about the use of coffee waste organic fertilizer. And in Figure 3, 89\% have used coffee waste organic fertilizer.

In marketing a product, you must have a clear and precise marketing strategy. So that product sales can exceed the target and can also compete with products from other companies so as to create a conducive and mutually beneficial competitive environment. Like that with the marketing of coffee waste organic fertilizers, the strategy used must be in accordance with the concept of incorporating all marketing mixes and using social media as a means of introducing it to the target product. To design a marketing strategy, it is necessary to determine market segmentation that is focused on consumers from a particular organization and determine consumers who are interested in coffee waste organic fertilizers, adjust target markets such as joining companies, organizations, farmers and others with the aim of increasing income and a good market position. online and offline. To be able to compare coffee waste organic fertilizer with other coffee waste organic fertilizers, the product must be able to receive suggestions from consumers and design strategies according to market demand, maintain price stability and product quality so that consumers are not disappointed to become customers and are better known throughout Indonesia and abroad (see Table 2).

Table 2. Question in the questionnaire

\begin{tabular}{|c|c|}
\hline Questions & Answer \\
\hline $\begin{array}{l}\text { How do you think the effect of organic } \\
\text { fertilizers on plants? }\end{array}$ & $\begin{array}{l}\text { make plants much better and healthier, } \\
\text { even though the growth takes a little } \\
\text { longer, but the plants produced are good } \\
\text { - } \\
\text { - } \quad \text { acceleratilize plants } \\
\text { - }\end{array}$ \\
\hline $\begin{array}{l}\text { What is the reason you choose organic } \\
\text { fertilizer? }\end{array}$ & $\begin{array}{l}\text { - can be made yourself, the materials used } \\
\text { are safe and easy to obtain } \\
\text { - } \\
\text { safer to consume the results of these plants } \\
\text { do not choose organic fertilizers, because } \\
\text { the nutrient content, solubility rate, and } \\
\text { nutrient release rate of organic fertilizers } \\
\text { are generally lower than inorganic } \\
\text { fertilizers }\end{array}$ \\
\hline
\end{tabular}




\section{International Journal of Research and Applied Technology}

$1(1)(2021) 61-69$

Journal homepage: https://ojs.unikom.ac.id/index.php/injuratechInternational

\section{Conclusion}

Digital marketing as a marketing communication strategy has a huge impact in increasing the selling power of organic fertilizers. Marketing a product must have a clear and precise marketing strategy. From product sales can exceed the planned target and can also compete with other companies' products so as to create a competitive environment that is conducive and mutually beneficial. People can know organic fertilizers through digital marketing with the strategies used in accordance with the concept of the marketing mix using websites and social media and by using digital marketing as a marketing communication strategy. Designing a marketing strategy is needed to determine market segmentation that is focused on consumers who use organic fertilizers on plants. Doing the target market by working with other companies is one trick to increase profits. Maintaining a product needs to know the comparison with other products by accepting suggestions from consumers and forming a marketing strategy so that demand does not decrease and maintain price stability. The use of digital marketing as a marketing communication strategy in the current era is very helpful for increasing marketing which is quite significant and products can be recognized in several cities.

\section{Acknowledgment}

All praise and great gratitude submitted to God Almighty who always gives gracious mercy and tremendous blessing that has helped the writer finishing the paper. The writer would like to deliver this thank to Dr. Ir. H. Eddy Soeryanto Soegoto, MT who gave the assignment so that the writer got a lot of lessons from the assignment given. The writer is also gratefull to the academic advisor who has helped the writer during this research. Colleagues who have participated in helping fill out the questionnaire which also has helped the writer.

\section{References}

[1] Soegoto, E. S., \& Utomo, A. T. 2019. Marketing Strategy Through Social Media. In IOP Conference Series: Materials Science and Engineering, 662(3), p. 032040.

[2] Soegoto, E. S., \& Rahmansyah, M. R. 2018. Use of internet as product marketing media using internet marketing method. In IOP Conference Series: Materials Science and Engineering, 407(1), p. 012053.

[3] Soegoto, E. S., \& Marica, A. 2018. Influence of Internet marketing on concert ticket purchasing. In IOP Conference Series: Materials Science and Engineering, 407(1), p. 012015.

[4] Soegoto, H. S., Putra, Y. H., Wahab, D. A., Kerlooza, Y. Y., \& Wahdiniwaty, R. 2019. The Influence of Online Transaction on Increasing The Profit of SMEs Using Structural Equation Modeling. In IOP Conference Series: Materials Science and Engineering, 662(3), p. 032025.

[5] Soegoto, E. S., \& Septiawan, H. 2018. Improving SME Marketing in Belitung District through Online Market. In IOP Conference Series: Materials Science and Engineering, 407(1), p. 012043.

[6] Kusniadji, S. 2017. Strategi Komunikasi Pemasaran dalam Kegiatan Pemasaran Produk Consumer Goods (Studi kasus Pada PT Expand Berlian Mulia Di Semarang. Jurnal Komunikasi, 8(1), pp. 83-98. 
[7] Soegoto, E. S., \& Akbar, R. 2018. Effect of the internet in improving business transactions with online market methods. In IOP Conference Series: Materials Science and Engineering, 407(1), p. 012051.

[8] Siahaan, W., \& Suntari, R. 2019. Effect of coffee dregs compost application on changes in chemical properties of Andisol Ngabab, Malang Regency. Journal of Land and Land Resources, 6, pp. 1123 -1132.

[9] Yeh, C. H., Wang, Y. S., Li, H. T., \& Lin, S. Y. 2017. The effect of information presentation modes on tourists' responses in Internet marketing: the moderating role of emotions. Journal of Travel \& Tourism Marketing, 34(8), pp. 1018-1032.

[10] Heliyon, 4, e00844. McNutt, J., \& He, Q. 2019. Spent coffee grounds: A review on current utilization. Journal of Industrial and Engineering Chemistry, 71, pp. 78 - 88.

[10] Bocconcelli, R., Cioppi, M., Fortezza, F., Francioni, B., Pagano, A., Savelli, E., \& Splendiani, S. 2018. SMEs and marketing: a systematic literature review. International Journal of Management Reviews, 20(2), pp. 227-254. 